\title{
Euthenasia, Birth Control or Planned Parenthood: Reflections on International Organisations and the Quest for NIEO
}

\section{Reginald Herbold Green}

we must appoint a committee ...

... on ways and means ...

one chairman will do for several committees ... and the rising cry of the people

resign, resign, resign ...

\section{-Coriolon: Ode for a Statesman T. S. Eliot}

The February, 1976, Ministerial Meeting of the Group of 77 (now well over 100 strong) resolved to create a permanent secretariat. The 7 th Special Session of the General Assembly in September, 1975 , set up a body of wise men to consider structural reform of the United Nations system. Even the IMF and IBRD--ponderously, slowly and cautiously as one would expect of weighty bankers-experiment with new strategy negotiating bodies which draw half of their membership from the Third World and have quite real potential power. Administrative and institutional reforms are, one might almost be intoxicated into believing, to be the twin midwives of the New International Economic Order or even the anointed guides to the New Jerusalem.

Or are they? Six years ago the Grand Assizes of Jackson and Pearson, combined with the Second Development Decade model on which Professor Tinbergen and his colleagues had lavished so much effort, were greeted with even more rapturous hosannahs. Then too a rationalisation, sanitisation, bureaucratisation and co-ordination of international organisations was to sweep away contradictions, controversies and constraints and make the world free of polemics, poverty and politics and safe for gross domestic product, growth and grandma." "Where are the snows of yesteryear? Where are the flowers of spring?" as Villon wrote from his prison cell. The administrative and institutional reform crusade of $1969-70$ could be 60 or 160 years in the past, so hard is it to recall, let alone recreate, the hopes

1 Certainly there were sceptics. At Barbara Ward's major launching conference on the Pearson Report, a majozity of the participants signed the Columbia Declaration which tepidly endorses the report as a weak, late first step but in effect rejects the entire growthmanship base of both Pearson and the Second Development Decade. But most of the and the Second Development Decade. But most of the
critics felt constrained to be muted and to say "Yes, but also ..." not "No!". and faiths it called forth. ". . . here we go round the mulberry bush ... this is the way the world ends ... not with a bang but with a whimper" is their epitaph as it has been of so many hopes to achieve a brave new world by administrative reform.

\section{Some basic issues}

What are the basic issues in administrative or institutional reform? When are changes needed? helpful? escapist? Is the whole subject banal at best and a destructive form of self deception at worst? A closer scrutiny does suggest a few guide-posts.

1. Institutions and their structures are machinery not products, means not ends. They cannot cause anything to happen. However, they can-by absence or inappropriateness-prevent things from happening or happening as rapidly or as effectively as desired.

2 Therefore before creating, reforming or eliminating an institution the first question which needs asking is: what ends is it intended to serve? The next question is: who benefits from achieving those ends and who loses enough to seek to block either the creation or the intended functioning of the institution?

3. From the identification of ends and actors it is possible to proceed to the question of methods. Eliminating illiteracy, transferring technology and reorganising the market relations for primary commodities can hardly be tackled by the same methods.

4. Only after ends, actors and method are identified is there an adequate framework within which to consider issues of institutional structure, membership, administration and operation. The Group of 25 on the UN System clearly faced the problem that it was set-the task of reforming institutions-without any prior agreement as to what the institutions were to achieve. It "solved" the problem by defining a set of global goals and UN roles in achieving them and then considering how to structure the UN institutional family to play those roles. This approach at least produces a potentially consistent approach. However, it runs the risk of confusing ends and means and also the risk of setting ends which are more 
representative of the advisors' views than of the interests of those they are advising. That danger is compounded when a high proportion of the advisors are administrators, managers and allied functionaries.

5. Because ends and methods vary, so will appropriate institutional arrangements. Operational and technical bodies (e.g. ICAO, UNICEF); global negotiating forums (e.g. in different ways the General Assembly, UNCTAD and perhaps the ILO); regional interest balancing forums (e.g. the Group of 77, OECD); special-purpose negotiating bodies (e.g. the former Group of 20 for global monetary reform); specialist advisory and technical units (e.g. DAC or the Third World's Group of 24 for monetary and financial matters); special interest-furthering bodies (e.g. OPEC and its parallel on the consumer side); and global or regional policy-setting units (e.g. the General Assembly, logically-if not in practice-UN Regional Commissions, the Councils of the East African Community, the EEC and the Andean Pact)-all these different types of organs have quite different institutional needs. To assume a standard all-purpose institutional model is usually the first several steps on the road to muddle and ineffectiveness.

6. Because both ends and methods and objective conditions (e.g. power of actors, technology, resources) change, the idea of once-for-all institutional reform is a chimera. Nor is it sensible to aim at uniformity and neatness ${ }^{2}$ because of the varied roles of institutions and because most institutions will have one predominant and other secondary roles. Articulation and co-ordination, not homegeneity and monolithicism, are practical operating goals for institution builders, reformers or eliminators.

\section{Goals and institutions}

If one applies these guidelines for the creation of institutions a key question emerges. What goals seriously sought by significant numbers of countries are made much harder to achieve by lack of appropriate institutional vehicles, and what type of institutions could fill the gaps? Looked at in terms of the quest for a New International Economic Order three glaring gaps exist: Third World technical-level co-ordination to advise and inform political forums; Third World and regional interest group and operational institutions which

2 For example institutional structure charts are both misleading and non-neutral. Misleading because institutions do not exist in two dimensional space nor, usually, with a very limited number of internal and external relationships. Non-neutral because a centralised, pyramidal hierarchy with top-down flows of orders, bottom-up delivery of information and strictly limited and prescribed participation and co-ordination at subordinate levels is easier to draw and explain and does "look better" on paper, however inappropriate to broader ends or even institutional operationality it may be. are genuinely of, for and in peripheral politieseconomies-societies; and ad hoc specialist negotiating forums which can arrive at technically feasible solutions informed by an understanding of basic political economic goals, constraints and power balances and therefore at least moderately likely to be ratified and scheduled for implementation at the political decision taking level.

In this context the Group of 77's decision to create a permanent secretariat may be a major step forward. If the peripheral economies are to act together as a "trade union of the poor" or in joint "co-operation against poverty" they require research and analysis at an operational level from a professional staff primarily concerned with identifying and articulating ways of furthering common interests. The duty of global institutions (e.g. UNCTAD) to all their members and the need for them to be able to act as credible honest brokers proposing acceptable compromises means that they cannot fulfil this role. (The Integrated Commodity Approach is misconceived as a Third World "extreme" position simply because no coherent and detailed Third World position to counterbalance the minimalist First World nonproposals has ever emerged. It is, in fact, a good example of an imaginative honest-broker initiative to achieve a compromise.) The limited data and professional resources of individual Third World countries add to the potential importance of a joint body but they do not create it. National units would (quite properly and inevitably) operate primarily from what they perceive as national interests and secondarily from their rather special perceptions of mutual interests. Further-partly as a result-professional and technical work done at the national level would be viewed with at least some scepticism by other Third World country decision-takers. Therefore, the need to pool resources, the need to co-ordinate and the need for an agreed technical infrastructure for political level strategies and proposals are complementary arguments for a "Third World OECD". Without it the unity of pronouncements will either be illusory, unimplementable because unarticulated, or non-negotiable because a shopping list has been substituted for a set of goals ranked in priority order, of tradeoffs and minimum packages.

\section{Common interest institutions}

The creation of a network of interest-group and operating institutions within the Third World cannot be handled both brieffy and comprehensively. The 1975 UNCTAD Group of Experts on Economic Co-operation among Developing Countries spent a signficant portion of their report on a host of illustrative examples in trade, 
industry, technology, research, consultancy, banking and investment banking in addition to the more standard proposals for reducing trade barriers, facilitating clearing and payments and promoting formal integration.

Their emphasis that what is critical is a perceived common interest more effectively pursued jointly than separately is a key one which, no matter how self-evident it may seem, is frequently overlooked. From it one can derive two critical conclusions. Membership minima and maxima are determined by the nature of the common interest. For example, the Union of Banana Exporting Countries probably cannot be functional so long as Ecuador is not a member; OPEC would be weakened by broadening its membership to encompass either every Third World country with a producing well or major industrial-economy producers who are net importers. Functional coverage should be limited to areas or to packages of areas in which, taken together, there is a clear joint interest. Adding unrelated areas can be divisive and dangerous. For example: the Group of 77 should not now seek to add domestic income distribution strategy to international economic relations strategy; OPEC is wise not to seek to co-ordinate-much less integrate-its members' development planning beyond the petroleum sector.

These observations suggest the need for a set of multinational institutions of and in the Third World as complex as those of and in the First. The Andean Pact's appropriateness does not logically militate against joint Venezuelan-Caribbean or Central American-Venezuelan institutions; the Carribbean Development Corporation is not an alternative to the Inter American Development Bank.

Brief, mass conferences of generalists cannot carry negotiations beyond the level of general agreed targets and constraints. Only more extended, limited working groups of representatives with specialised knowledge can do that. No matter how self-evident that proposition may appearnor how well established it may be in the sphere of industrial relations negotiations-many international negotiations, and especially much of the history of UNCTAD, exemplify failure to act on it.

\section{New global institutions}

UNCTAD might succeed in building on the very general and tentative fabric of apparent consensus on short term international economic order goals and possible means for achieving them which the 7th Special Session reached. It might arrive at agreement on a dozen priority opera- tional goals (e.g. Joint Commodity Fund, some variant of indexation, phased freedom of access for Third World manufactures, eight major commodity agreements) and on target dates for achieving them. Even if it does, however, unclarity remains as to how such a skeleton of agreement could be clothed with the muscles and skin of detailed provisions and institutional modalities. Its universal membership committees with broad mandates and generalist participants could not get on with the job.

The solution would appear to lie in a series of smaller, specified-purpose, limited-life-expectancy bodies with membership based on a constituency system and varying from topic to topic. The Group of 20 was perhaps the first exercise along these lines. It was a procedural success. Its efforts were in the end swamped and its mandate rendered irrelevant by the 1974-7? world monetary disturbances, born of the inflation and recession in the major capitalist industrial economies and of OPEC's unilateral moves-after a decade of negotiation with those who declined to negotiate-to the very partial and very unbalanced alteration of the international economic order it could achieve. But that should not cloud either the ability of the $G 20$ to negotiate its way towards rational and agreed conclusions nor the fact that 45 per cent of its membership was Third World. 3 The principle of universal membership is the barrier to such an approach. Five comments can be made :

(a) the terms of reference and membership of specialist negotiating bodies would normally come from universal (or regional) membership institutions;

(b) the results of any such negotiating body would require ratification and implementation by universal membership bodies and by individual governments;

(c) Third World effectiveness at this level is not really furthered by an automatic voting majority (as opposed to half the seats) because to be a success a negotiation must reach conclusions at least minimally acceptable to those whose ratification is essential for implementation;

(d) a constituency system would allow each state to put its views (and to place an advisor on its representatives' team) while limiting the awesome manpower demands which participating fully in every negotiation would entail for the smaller states;

\footnotetext{
3 The "missing" 5 per cent was Australia-indubitably a dependent and peripheral economy but one which to datc has such soecial relations with, and attitudes toward. the major capitalist industrial economies that it can hardly be classed as Third World.
} 
(e) as a result, the real bargaining expertise and power of the Third World and-probably-of the smaller industrial economies would be enhanced.

\section{Gaps and overlaps}

The logical complements to creating new institutions are first to eliminate overlaps and interstices $^{4}$ in existing institutions and second to rebuild those which have proved inadequate. How one proceeds to do the former depends very much on the degree to which effective coherence can be achieved in goal-setting and ongoing co-ordination at operational level. And with respect to the latter any reformer must face the fact that however hard it may be to reconstruct an inappropriate institution it is usually still harder to kill it off and start afresh.

At the strategic and policy levels overlap is particularly damaging. It may be desirable for both UNCTAD and the World Employment Conference to include trade in manufactures and the relevance of a new world economic geography to a New International Economic Order but only if they do so within a common framework and with a fairly clear division of labour on who negotiates what. ${ }^{5}$ Various global institutional patterns-notably not including that of the present UN extended family-might serve that end probably including the main approaches suggested in the Group of 25 report. The main thrusts would be :

(a) to create clear and coherent relations between strategy and policy making units on the one hand and negotiating or operational units on the other;

(b) to seek a broad division of labour among the latter units but not to the point of eliminating efficiency and substance in the name of neatness and non-overlap;

\footnotetext{
4 Very often these are joint. ILO-UNIDO-UNESCO-UNCTAD all deal with technology transfer and development and do so with inadequate co-ordination. As a result the transfer of technology aspects are handled in a somewhat duplicatory and contradictory manner while the development of innovative and development capacity in Third World countries usually falls into the inter-institutional interstices.

5 As it happens WEC is not primarily a negotiating forum and will be weakened by any attempt to transform it in that direction. Its key themes of basic needs, adjustment assistance and multinationals migration are ones which-at least todaymust be dealt with by co-ordination of national policies among mutually concerned states. Operational global decisions are not attainable. For the industrial world to attempt to demand a Basic Needs-oriented strategy by the Third World as a quid pro quo for NIEO would at best be romantic as a quid pro quo for NIEO would at best be romantic
utopianism, and, in practice, hypocritical and counterproductive. UNCTAD, per contra should be a forum concerned with identifying concrete areas for future, and workabls terms of reference for present, negotiations towards multinationaland often global-action. The more it wanders into "statesmanlike" discussions and "agreements" to bear mutual interests in mind instead of laying the foundations for negotiation, the worse. Co-ordination should be relatively easy-UNCTAD's worse. Co-ordination should be relatively easy-UNCTAD's
potential areas of strength are WEC's areas of weakness and vice versa.
}

(c) to create means to co-ordinate the implementation efforts of different agencies which are more concerned with jointly solving problems than with the "territorial imperative"-the jealous protection of the agencies' spheres of interest.

Institutional inadequacies often arise from a lack of any clear set of purposes-e.g. the UN Regional Commissions--or from having a set of aims so diffuse and so little ranked in priority order that no coherent raison d'etre or principles for selecting activities emerge-e.g. UNESCO. Both are usually associated with a lack of any operational criteria for measuring success or failure-not surprisingly since those who do not know where they are trying to go are likely to be unclear whether they are proceeding in the right direction let alone what their probable arrival time might be.

In this area three approaches are potentially useful :

'a) to identify a set of reasonably specific goals for which a real constituency exists, which the institution could further and for which it is at least as competent and appropriate a vehicle is any existing alternative; 6

(b) to structure the institution and its operations toward furthering the identified goals in a coherent way with clear priorities;

(c) to create an agreed set of criteria for evaluating results. These should flow from the goals (e.g. growth of GDP is not a usuable criterion for measuring progress toward poverty eradiction). They should measure outputs not inputs (e.g. expenditure on technical assistance is an input, transfer of knowledge and capacity to use and develop it is the output one presumptively seeks to measure). They should be intelligible to decision takers (e.g. a composite index of dozens of weighted items usually fails this test while half a dozen separate measures might be quite readily understood and acted on). They should not mystify or disguise under the guise of professionalism or precision (e.g. most present versions of social cost benefit analysis ${ }^{7}$ ).

6 If no such goals can be identified then the institution should be wound up, however high the hopes with which it was created and, indeed, however valuable it may once have been.

7 The problem is not that "non-economic" (i.e. non-GDP. growthmanship or non-profit maximising) variables are irrelevant. Rather it is that in seeking to put precise, subtly computed monetary prices on them there is a grave danger of creating an aura of objectivity and precision and thus failing to pose critical choices and value judgements to decision takers. 


\section{Priorities}

To argue for the setting of priorities logically creates an obligation to state one's own. To argue that uniformity and homogeneity are false goals unfortunately creates a countervailing obligation not to present one change as of transcendant significance dwarfing all others and clearly viable by itself. In the context of the quest for a New International Economic Order probably three institutional and administrative developments have joint (and interacting) top priority:

(a) the creation of a technical and professional capacity to support a global Third World decision-taking forum (i.e. the 77 or the NonAligned) by providing the information and analysis it needs.

(b) setting up operational specialised negotiating bodies which can transform the broad parameters of policy into detailed proposals for ratification and implementation (e.g. to follow through from the forthcoming UNCTAD);

(c) beginning to build up a network of specialised Third World institutions to further clearly defined common interests, their scope and membership being related in each case to the particular common interest (an area in which the proposed 77 or Non-Aligned permanent secretariat could play useful stimulative, catalytic and co-ordinating roles).

If this selection suggests to the reader that in many international organization reform proposals too much priority is placed on global bodies, on comprehensive UN system rebuilding and on management consultant type quests for efficiency, the author would not disagree. Those elements are important but a New International Economic Order cannot be constructed until the Third World's ability to co-ordinate and direct its potential power to specific, attainable objectives (on the "trade union of the poor" and the joint "co-operation against poverty" fronts) is enhanced and until there are forums in which effective negotiation is possible. To achieve the second requires global action; but the first must flow from a broader perception of potentials, possibilities and priorities by Third World decisiontakers and technicians.

Collective self reliance and NIEO negotiating strategies cannot be provided as packaged technical assistance imports. First and Second World institutions or individuals can only play an ancillary role in promoting them no matter how intelligent and committed they may be. 